\title{
IDEAS \& Development of a new long-term drought INNOVATIONS resilient soil water retention technology
}

\author{
Yasemin Kavdir, Wei Zhang, Bruno Basso, and Alvin J.M. Smucker
}

I

ncreasing frequencies of drought coupled with increasing populations are requiring more water for irrigated agriculture. As global populations approach 9 billion by 2050, even more water will be required to produce an estimated 60\% to $70 \%$ more food (McKenna 2012). Production of these greater quantities of food require, at current water use efficiency rates, 50\% more water (Clay 2004). Consequently, the growing demand for food and fiber combined with dwindling water supplies (in terms of both quantity and quality) available for agricultural irrigation require new soil technologies that conserve water.

In the United States, the Ogallala Aquifer supplies 30\% of groundwater for irrigated agriculture, and water supplies are being rapidly exhausted, especially in the southern regions (Steward et al. 2013). In other regions, reduced snow cover and surface water supplies are unable to sustain traditional irrigated agriculture, and severe drought is experienced more often (Clay 2004). Construction of large reservoirs along international and continental rivers is threatening natural water flow to communities and nations downstream. More frequent droughts with longer-term severity cause uncertainty in commodity prices and global food supplies.

During this last century, global freshwater withdrawal increased more than six-fold, from 579 to $3,750 \mathrm{~km}^{3} \mathrm{y}^{-1}$ (900 $\mathrm{mi}^{3} \mathrm{yr}^{-1}$ ), due to increasing industrialization, human and animal populations, and irrigated agriculture (Clay 2004). The agricultural

Yasemin Kavdir is an associate professor in the Soil Science and Plant Nutrition Department, Canakkale Onsekiz Mart University, Canakkale, Turkey. Wei Zhang is an assistant professor in the Department of Plant, Soil, and Microbial Sciences and the Environmental Science and Policy Program, Michigan State University, East Lansing, Michigan. Bruno Basso is an associate professor in the Geological Sciences Department and the W.K. Kellogg Biological Station, Michigan State University, East Lansing, Michigan. Alvin J.M. Smucker is a professor in the Department of Plant, Soil, and Microbial Sciences and the Environmental Science and Policy Program, Michigan State University, East Lansing, Michigan. sector consumes approximately $70 \%$ of all freshwater, more than twice the amount of industrial, municipal, and other users (Clay 2004). Much of the growth in agricultural water use has occurred in Australia, Greece, Portugal, and Turkey, where agriculture's share of total water use has exceeded 75\% (OECD 2008), and in some countries, agricultural use has approached 98\%. The annual unsustainable depletion of aquifers has surpassed 163.6 billion $\mathrm{m}^{3}\left(5,777 \mathrm{ft}^{3}\right)$ (Kimbrell 2002), and approximately 75\% of all irrigated land is located in developed countries where agriculture uses $73 \%$ to $88 \%$ of freshwater supplies. The astonishing component of this high water consumption is that approximately $60 \%$ of all supplemental irrigation water is wasted (Clay 2004).

Reducing deep percolation losses of root zone soil water is becoming a major research focus among agricultural and hydropedological scientists and engineers (Graham and Lin 2012). This report summarizes another opportunity for a new soil water-saving technology to join the innovative options for increasing food and fiber production with less water.

\section{EARLY REPORTS OF IMPROVED SOIL WATER RETENTION}

Subsurface water retention has been practiced by burying leaky clay pots in arid and semiarid soils of Northern Africa and Iran for thousands of years. These same manually buried irrigation systems continue to be used in some arid lands in Africa, Asia, and Latin America (Alemi 1980; Daka 2001; Bainbridge 2001; Gao et al. 1996) and are reported to reduce soil salinity, increase irrigation efficiency, decrease irrigation frequency, improve crop yield, and reduce labor (Daka 2001). However, the pots experience microbial plugging that lowers wall permeability resulting in lower plant productivity (Sun et al. 2000).

Alternatively, physical water barriers, mimicking natural thin clay layers, have been placed at certain depths in permeable soils. Spatially distributed clay layers with low permeability within some highly permeable soils increase the retention of both soil water and nutrients (Hillel 2004). Clay mixed into surface horizons of sand soils (Al-Omran et al. 1991; Ismail and Ozowa 2007) and incorporations of thin layers of clay water barriers located 15 to $30 \mathrm{~cm}$ (6 to $12 \mathrm{in}$ ) beneath sand soil surfaces (Saunders 1941; Mortland et al. 1957; Chen and Qian 1984) provide modest improvements in soil water retention crop yield. However, applications of clay and silt materials in sandy soils are costly and create heterogeneous soils (Ismail and Ozowa 2007). Manual installations of polyethylene (PE) sheets have also successfully increased plant yields in sandy soils (Garrity et al. 1992; Kavdir et al. 2012). Although clay and polymer layers increase soil water holding capacity, the absence of machine installations have prohibited their adoption (Erickson 1972).

Hansen and Erickson (1969) developed a subsurface asphalt spraying machine that lifted soils $\sim 10 \mathrm{~cm}$ (4 in) while spraying hot cation emulsions of liquid asphalt at 50 to 60 cm (20 to 24 in) depths. Asphalt was immediately covered by soil passing over the 110 cm (43 in) wide cultivator blade. Multiple passes of these overlapping asphalt moisture films, $\sim 4 \mathrm{~mm}$ (0.16 in) thick, provided a near continuous moisture barrier across the landscape. Prevention of gravitational leaching retained and doubled the percentage of volumetric water content (VWC) in the rooting zone above the asphalt barriers (Erickson 1972). Erickson et al. (1968a and 1968b) and Brunstrum et al. (1967) reported vegetable and row crop increases on asphalt barrier-improved sandy soil field experiments across six states and in three nations. Sixteen agricultural and horticultural crops were tested. Soil water contents were greater above asphalt barriers than control treatments without asphalt retainers. However, too little rainfall resulted in near crop failure as root growth was confined to soil volumes above asphalt barriers. Excess rainfall occasionally flooded the root zone causing crop loss and failure (Saxena et al. 1971; Erickson et al. 1968a, 1968b).

Asphalt soil water barriers have also been reported to reduce deep percolation 
of nitrogen $(\mathrm{N})$ with resultant increased crop production on sandy soils (Robertson et al. 1973; Saxena et al. 1971, 1973). Sugarcane (Saccharum officinarum L.) biomass yields for three years of harvesting were 1.56-fold greater $\left(67.8 \mathrm{t} \mathrm{ha}^{-1}\left[30.3 \mathrm{tn} \mathrm{ac}^{-1}\right]\right)$ on plots with asphalt barriers at $75 \mathrm{~cm}$ (30 in) depths than controls without barriers (Erickson et al. 1968b; Smucker 1969). Although all asphalt barrier studies retained more $\mathrm{N}$ within the soil profile above the barriers, sugarcane yield was lower when grown on sands with shallow, $50 \mathrm{~cm}$ (20 in), asphalt barriers due to oxygen $\left(\mathrm{O}_{2}\right)$ deficiency and $\mathrm{N}$ volatilization (Smucker 1969; Erickson et al. 1971). Sugarcane grown on asphalt barriers at $75 \mathrm{~cm}$ (30 in) depth required only $32 \%$ of the supplemental irrigation required by controls. Asphalt water retention barriers saved $841,900 \mathrm{~L} \mathrm{ha}^{-1}(90,083$ $\mathrm{gal} \mathrm{ac}^{-1}$ ) of irrigation water annually, producing $104.4 \mathrm{t} \mathrm{ha}^{-1}$ (46.6 $\mathrm{tn} \mathrm{ac}^{-1}$ ) or 92\% more sugarcane biomass and 76\% (12.1 $\mathrm{t} \mathrm{ha}^{-1}[5.4$ tn $\left.\mathrm{ac}^{-1}\right]$ ) more sugar than controls in subtropical Taiwan. Asphalt water barriers installed at $75 \mathrm{~cm}$ depths improved irrigation water use efficiency $333 \%$ and improved shoot to root ratios by $241 \%$ (Smucker 1969). Asphalt barriers in sands established paddy rice (Oryza sativa L.) that produced an average of $208 \%$ more grain for spring and summer crops while requiring only $20 \%$ of supplemental irrigation water required by controls (Erickson et al. 1968a; Smucker 1969).

Mechanical installations of a thin layer of hot asphalt applied below the root zone in sand soils in western Australia also doubled soil water holding capacities, improved kiwi tree (Actinidia deliciosa) growth, and displayed less nutrient stresses (figure 1), producing more kiwifruit than controls. In South Africa, asphalt barriers placed at $60 \mathrm{~cm}(24$ in) depth below the soil surface increased cotton (Gossypium hirsutum L.) and alfalfa (Medicago sativa L.) production by $25 \%$ and 30\% (Sumner and Gilfillan 1971). Sugarcane biomass increased 1.5-fold when grown on dryland Fernwood sands series in South Africa (Sumner and Gilfillan 1971). Rao et al. (1972) reported 70\% less irrigation water was required to increase yields of rice grown on asphalt barrier-improved sandy loam soils in India. Vegetable yield studies by Scarborough and Liebhardt (1973) increased by $46 \%$ to $58 \%$ on bitumen barrier compared to control sandy loam soil.

\section{Figure 1}

Aerial view of water barrier research improvement for two and four-year-old Kiwi fruit trees growing on sandy soils near Adelaide, Australia. Note the dark blue-green leaf color and smaller tree size on sands without asphalt water barrier and nonirrigated. Water retention barriers increased both growth and production.

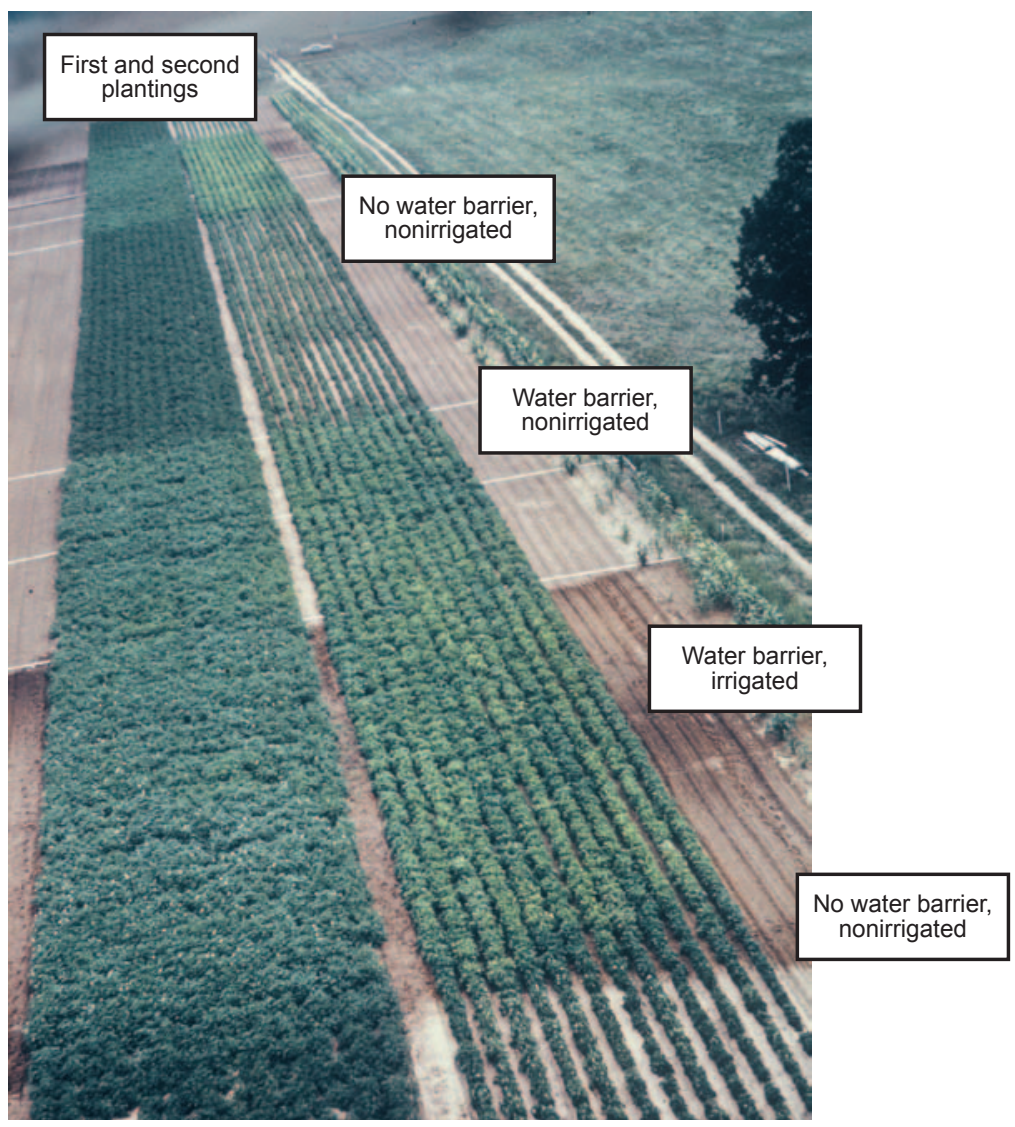

Garrity et al. (1992) installed large PE sheets at 25 and $40 \mathrm{~cm}$ (10 and 16 in) soil depths to increase rice grain yields by 1.8 to $2.1 \mathrm{t} \mathrm{ha}^{-1}\left(0.80\right.$ to $\left.0.94 \mathrm{tn} \mathrm{ac}^{-1}\right)$ in northeast Thailand and Philippines on loamy sand to clay soils. Rice yields were zero without barriers in Thailand. Rice yields grown on polymer lined sands ranged from 3.2 to $5.1 \mathrm{t} \mathrm{ha}^{-1}$ (1.4 to $2.3 \mathrm{tn} \mathrm{ac}^{-1}$ ) with water barriers and 1.5 to $3.3 \mathrm{t} \mathrm{ha}^{-1}(0.7$ to $1.5 \mathrm{tn} \mathrm{ac}^{-1}$ ) without barriers in Philippines. Shallow water retention barriers, placed at $22.5 \mathrm{~cm}$ (8.9 in) depths, further reduced rice grain yields.

Ren et al. (2000) studied the barrier placement on the dynamics of soil water moisture profile throughout wheat (Triticum aestivum L.) production and reported how subsurface barriers have tremendous potential for increasing soil water retention and associated crop production on sand soils. Wang et al. (2001) also reported that soils with subsurface barriers have greater increases in organic matter and plant nutrients. They also suggested higher quantities of sand fractions $<0.1 \mathrm{~mm}$ (0.25 in), were retained in the cultivated depths of 0 to 30 $\mathrm{cm}$ (0 to $12 \mathrm{in}$ ) when barriers were present, compared to plots without the barriers. This first report of greater retention of fine mineral fractions suggests SWRT polymer membranes may also accumulate clay layers which retain more water in plant root zones for centuries.

In addition to the above field crops, subsurface polymer barriers have also been used to improve turfgrass cultivation in Gansu (Liu et al. 2008; Liu et al. 2005). Demirel and Kavdir (2013) reported water savings of $35 \%$ and $70 \%$ compared to control sands without water-saving membranes while producing the highest quality turfgrass and 39\% more turfgrass clippings when water impermeable poly- 
mer layers were installed at 30 and $40 \mathrm{~cm}$ (12 to 16 in) to maintain water contents at $66 \%$ field capacity in the sandy soils (Kavdir et al. 2012). Results have shown that HYDRUS-2D, a numerical simulation model program (Šimůnek et al. 2008), can succesfully predict soil water contents above and below subsurface water retention barriers (Demirel et al. 2012).

During the past 50 years, innovative researchers have explored a range of technologies that retain greater quantities of soil water for longer periods of time. These reports have demonstrated how subsurface soil water retention technologies double and sometimes saturate soil water content. Although different attempts to install long-term water-retaining barriers demonstrated some success, the absence of machine installations prohibited their adoption (Erickson 1972).

\section{NEW MECHANICAL INSTALLATION DEVICE FOR SPATIALLY DISTRIBUTED IMPERMEABLE MEMBRANES}

All previous methods of water retention did not evolve into precise mechanical installations of water-retaining membranes. In 2009, scientists at Michigan State University began to design mechanical installation cultivators that would install contoured engineered PE membranes that doubled VWC within the upper 50 $\mathrm{cm}$ (20 in) of sand soils. Hydropedological tests explored the highest water retention capacity by 3 mil thickness impermeable PE membranes. Results showed that low frequency drainage holes in PE membranes within sand columns retained much more water than control treatments yet drained gravitational water when soil became saturated (Yang et al. 2012). Preliminary testing led to designs and constructs of chisels spatially guided by real time kinematic (RTK) global positioning system (GPS) controls to precisely position uniformly spaced subsurface contoured engineered PE films (figure 2). These soil water retention technology (SWRT) membranes are strategically positioned at two depths without inverting sand soil profiles during installation. Spatial arrangement of these water impermeable membranes was designed to provide an optimal balance between retention of capillary water and drainage of gravitational water across soil textures, even during excessive rainfall (Cameron et al. 2013). Installation of SWRT waterand nutrient-retaining membranes has been designed to maximize water holding capacities in sand soils. These U-shaped polymer membranes, having aspect ratios of $2: 1$, were installed at two depths (figure 2). Membranes of the deeper tier were installed with their base 25 to $30 \mathrm{~cm}$ (10 to $12 \mathrm{in}$ ) deeper than the maximum capillary rise within sand columns. In subsequent passes, the same membrane installation chisels were raised 17 to $20 \mathrm{~cm}$ (7 to 8 in) and offset $30 \mathrm{~cm}$ (12 inches) to fill the soil gap between the lower membranes (figure 2). Soil volumes retained within the U-shaped membranes of both deep and shallow tiers absorbed and retained up to saturatedVWC of vertical drainage water, which drained to field capacity within less than two days. Intermembrane spaces permitted over the top drainage of excess precipitation rates greater than $6 \mathrm{~cm}$ (2 in) in 24 hours (Yang et al. 2012; Smucker and Basso 2014). These spaces also enable a few roots to bypass the SWRT membrane cluster. A SWRT membrane installation device implement has been designed and patented, US Patent No. 20130209172 by Michigan State University
Technology. New commercial SWRT membrane installation devices are now licensed for commercial production, sales, and service (RWF BRON, Woodstock, Canada) and are patented in 25 additional countries for commercial sales and service. These new SWRT membranes double the VWC capacities of most highly permeable soils converting them into sustainable long-term agroecosystems while reducing deep leaching. Installation of these designer membranes into sand and sandy loam soils has been modeled to predict $283 \%$ increases in maize (Zea mays L.) grain yields (figure 3). Similar modeling predictions for sandy soils in Michigan are being processed to identify the best locations for SWRT demonstrations on farms during the 2014 and 2015 growing seasons.

Following extensive laboratory testing, these newly designed SWRT membrane systems have surpassed their proof-of-concept that plant roots can grow into, around, and beyond SWRT membrane depths during extensive field testing (Smucker et al. 2009c; Yang et al. 2012; Smucker et al. 2012). Irrigated vegetable production increased by $43 \%$, and irrigated maize production increased by 238\% (Smucker and Basso 2014). The total biomass of irrigated

\section{Figure 2}

Diagrammatic representation of volumetric water content (VWC) gradients within and above soil water retention technology (SWRT) membranes 24 hours following irrigation or significant precipitation events. One can observe SWRT membranes are designed to double soil water holding capacity in the root zone of sand soils. Bowl or U-shaped SWRT membranes in the root zone provide continuous supplies of plant available water. These membranes, with aspect ratios of $2: 1$, are mechanically installed to soil depths of 25 to $60 \mathrm{~cm}$ depending upon soil texture.

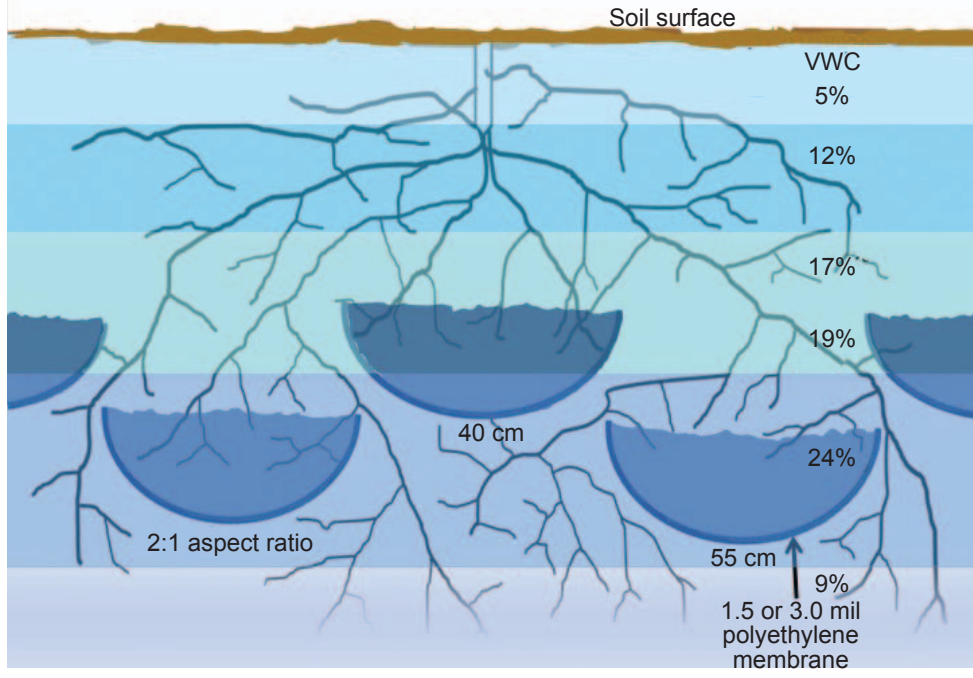




\section{Figure 3}

System approach to land use sustainability (Basso 2006) modeling of maize grain yields projected $283 \%$ yield increase by soil water retention technology (SWRT) membranes installed below plant root zones of nonirrigated sandy soils near Brisbane, Australia. Irrigation of maize growing on sand underlined with SWRT membranes increased $25 \%$ beyond irrigated sands without water-retaining membranes. SWRT membranes also increase maize production on nonirrigated and irrigated sandy loam soils although to a lesser extent of $22 \%$ and $32 \%$.

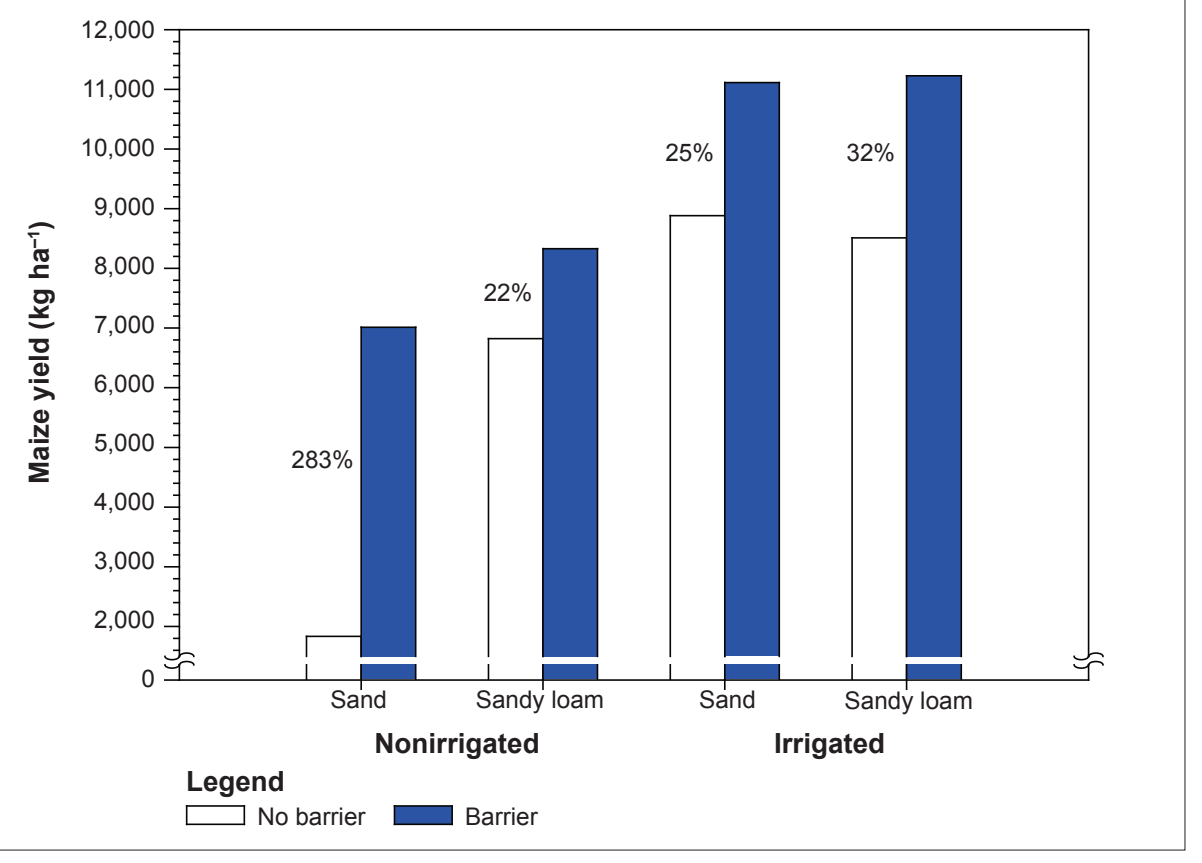

\section{Figure 4}

Accelerated maize growth, in rows on the right side of the photo was due to the soil water retention technology membrane retention of soil water in the plant root zones of irrigated sands. Maize growth shown in three rows on the left side of the photo was due to the absence of stored water in the root zone. Photo taken in East Lansing, Michigan, on June 29, 2012.

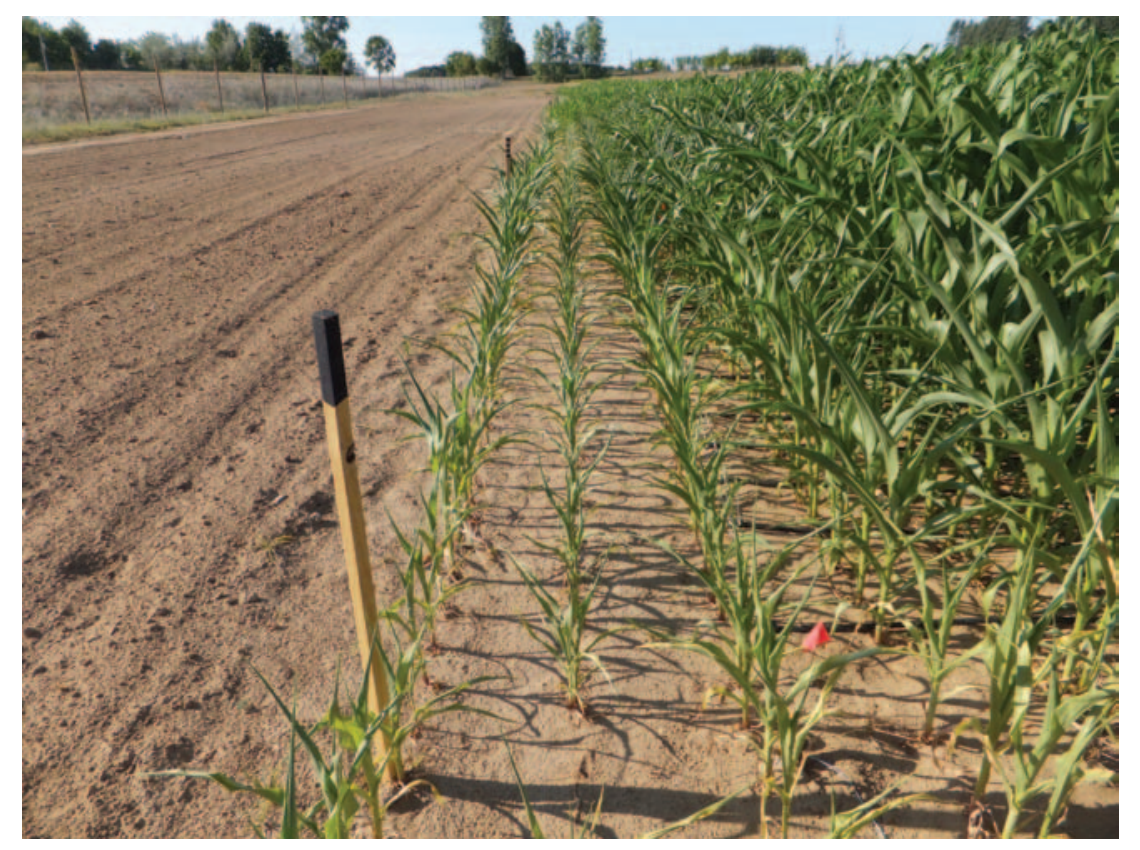

maize growing on SWRT membranes during the dry 2012 summer in Michigan nearly doubled (93\% increase) total plant biomass production compared to irrigated controls (Smucker and Basso 2014).

In addition, these newly designed SWRT membrane configurations (figure 2) retained up to $157 \%$ more plant-available water along with more $\mathrm{N}$ and potassium (K) within plant root zones of sandy soils, dramatically accelerating plant growth, as illustrated in figure 4. Proper irrigation scheduling of more frequent irrigations daily could reduce short-term and longterm soil drying cycles to $50 \%$ of the 37 to 53 extensive dry and wet cycles per crop season (unpublished soil probe data). These yield increases were parallel and often exceeded water savings by continuous layers of asphalt reported to increase rice and sugarcane yields by Erickson et al. (1968a and 1986b), Amoco (1970), Brunstrum (1967), and Brunstrum et al. (1967). These U-shaped SWRT impermeable membranes are designed to increase water-use efficiency up to three-fold in temperate regions, and we predict up to eight-fold in tropical regions, when combined with subsurface drip irrigation systems. Therefore, we believe applications of SWRT watersaving membranes to the sandy soils in many rural areas have the potential for transforming lives and landscapes by producing sustainable cellulosic biomass for renewable biofuel production without competing with agricultural land in food production. We believe current production of $<3 \mathrm{tha}^{-1}$ $\left(<1.3 \mathrm{tn} \mathrm{ac}^{-1}\right)$ of cellulosic biomass on sandy soils can be increased to $>10 \mathrm{t} \mathrm{ha}^{-1}(>4.5 \mathrm{tn}$ $\mathrm{ac}^{-1}$ ) with supplemental irrigation and optimal fertilization under prescription-based best management practices that reduce groundwater contamination (Smucker et al. 2009b, 2010). We assume these unprecedented intensifications of agriculture on coarse-textured soils also offer additional ecosystem services, i.e., less greenhouse gas emissions, fewer root diseases, and increased soil carbon (C) contents (Robertson and Vitousek 2009).

These U-shaped water-saving membranes, having 2:1 width to depth aspect ratios (figure 2), retain more soil water content for longer time periods in arid regions receiving site-specific irrigation 
frequencies and rates that establish optimal soil VWC between 15\% and 17\% (Smucker et al. 2012; Smucker and Basso 2014). Soil water retention technology membrane-improved soil water contents provide greater hydraulic conductivity that meets optimal plant available water without deep soil water losses. These data give us confidence that properly installed SWRT membranes can provide longer time periods of plant-available water and nutrients within plant root zones between supplemental irrigation and precipitation events. Future research should be designed to explore water savings and irrigation water use efficiency during an entire crop season, when subsurface drip irrigation tape is installed directly above SWRT membranes in sand soils of arid and semiarid regions where irrigation water is saline and scarce.

Many process-level biogeochemical mechanisms (Park et al. 2007) can be improved in coarse textured sandy soils low in soil organic matter by appropriately engineered membranes installed at proper depths, including greater soil C storage and fewer hydropedologic losses of N and K (Erickson et al. 1971; Robertson and Vitousek 2009). Sand soils without water-retaining treatments are known to have saturated hydraulic conductivities

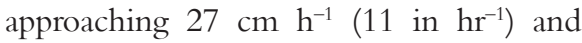
provide highly aerated root zone volumes without anaerobic conditions. Installing SWRT membranes into sandy loam and loamy soils in humid climates will most likely require wider spaces between membranes having aspect ratios of 3:1 and 2.5:1 to avoid soil aeration stresses following periods of excess precipitation. Soil water retention technology ameliorated droughty sands should open up literally millions of unused highly permeable natural soil resources for expanding cellulosic biomass production for biofuels, vegetables, and row crop grain on sandy soils. We also assume there are many additional research opportunities to expand the usefulness of SWRT membranes into unknown and exciting areas that contribute to food production and animal and agroforestal communities across North America and globally.

Research quantifying changes in these processes is necessary before we can fully

\section{Figure 5}

Accelerated maize and soybean growth in rows grown on irrigated sand lined with soil water retention technology (SWRT) water and nutrient retaining membranes are shown on the left and right sides of the photo. Nonirrigated control plants growing on sands without SWRT membranes are located in the middle. Nonirrigated border maize plants are in the foreground. Photo taken in East Lansing, Michigan, in 2013.

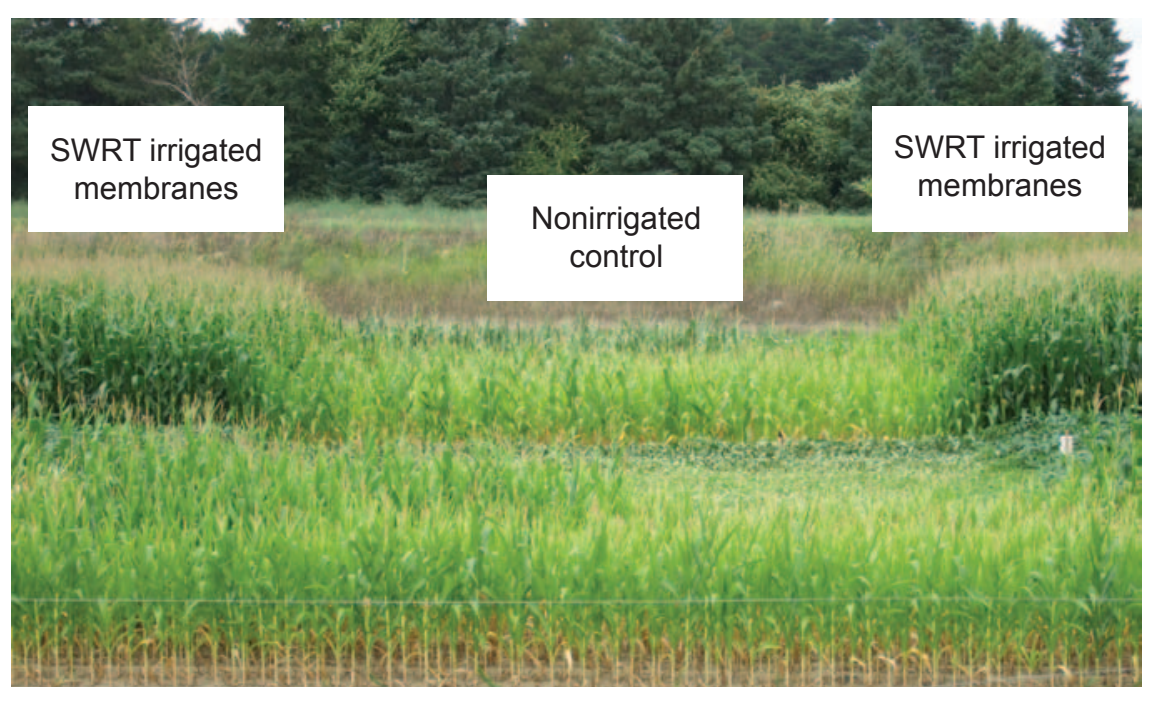

identify all that SWRT membranes may offer to sustainable production on different soil textures among different climates. Professional membrane installers are being trained, licensed, and certified to install SWRT water- and nutrient-saving membranes having zero margins of error at rates of 2 to 3 ha d $^{-1}$ ( 5 to 7 ac day $^{-1}$ ). Smaller models of SWRT membrane installation implements for gardens, lawns, and small-holder farms internationally are awaiting further field testing for commercial distribution.

As with all new technologies, there will be a need for additional training of farm managers to accurately manage SWRT systems coupled with prescription-based best management practices for SWRT improved sand soils for maximum production. As more new paradigm-changing technologies surface, additional educational cooperation between owners and operators of commercial and large farms, local equipment dealers, and soil water engineering firms becomes more essential. As employment increases, local communities surrounded by sand soils will prosper. Newly franchised businesses are emerging among farm equipment sales and service companies. As SWRT field research continues, new precision management practices will profit farmers, resulting in greater farm gate receipts that improve lives and landscapes of agricultural communities.

\section{CONCLUSIONS}

This new SWRT approach has great potential for conserving rain and irrigation water in sandy soils in a most cost-effective manner. Irrigated SWRT membrane promotion of maize and soybean (Glycine $\max$ L.) growth (figure 5) demonstrates how accelerated yields generate excellent returns on investments of SWRT watersaving membrane installations. Preliminary data identify the full return on investment for SWRT enhanced maize production seldom exceeds four years. Since there is no maintenance of properly installed SWRT membranes, whose projected functional viability lifespan is 47 to 300 years (Hakkarainen and Albertsson 2004), all additional water and nutrient savings combined with greater production potentials provide increasing net profits for many decades. The newly developed commercial SWRT machines, manufactured to install water- and fertilizer-saving membranes into multiple soil types, have the potential for converting at least 120 million ha (300 million ac) of marginal sandy soils into sustainable agricultural production in the United States. Globally, hundreds of millions of hectares of marginal sands can 
be converted into sustainable agricultural productive lands, as new water sources continue to be discovered. Additional onfarm collaborative studies with irrigation industries, combined with enhanced prescription management systems, offer the potential for expanding food production on large farms and smallholder farms in developing countries. Less water use for more water-use efficient food production reduces competition for regional water by households and urban centers (Barrett 2010). During conversions of marginal sandy soils into sustainable production, new and innovative subsurface drip irrigation and other water-saving irrigation technologies need to be combined with minimum tillage and annual cover crops.

Soil water retention technology watersaving soil treatments must be adopted to eliminate the high risk and uncertainty associated with plant water deficits. This new SWRT has the potential to ameliorate sandy soil regions that provide multiple ecosystem services to rural communities experiencing job losses and depressed economies (Smucker et al. 2009a, 2009b). Since most rural farming operations insure planted crops to financially offset unpredictable weather and climate conditions that reduce plant productivity, SWRT-enhanced plant production offers additional crop protection, reducing insurance payments for crop losses enabling industry-wide reductions in crop insurance premiums, a win-win savings for both producers and insurance companies. Soil water retention technology transformations of highly permeable soils into sustainable agricultural production enables farmers to achieve the necessary $70 \%$ expansion of global food production by 2050 with less water. SWRT will continue to secure water for food that meets the nutritional needs of billions even as climates change across continents.

\section{ACKNOWLEDGEMENTS}

This material is based upon work supported by the Michigan Initiative for Innovation and Entrepreneurship Program, AgBioResearch at Michigan State University and the USDA Natural Resources Conservation Service, under NRCS Conservation Innovation Grant Number 69-3A75-13-93.

\section{REFERENCES}

Alemi, M.H. 1980. Distribution of water and salt in soil under trickle and pot irrigation regimes. Agricultural Water Management 3:195-203.

Al-Omran, A.M., M.A. Mustafa, A.M. Al-Darby, and A.A. Shalaby. 1991. Gel conditioned barriers for water management of sandy soils. Irrigation Science 12:7-12.

Amoco. 1970.The Asphalt Moisture Barrier.American Oil Company Bulletin, Whiting, IN: Amoco.

Bainbridge, D. 2001. Buried clay-pot irrigation: A little-known but very efficient traditional method of irrigation. Agricultural Water Management 48:79-88.

Barrett, C.B. 2010. Measuring food insecurity. Science 327:825

Basso, B. 2006. Water use efficiency in crop production at different spatial and temporal scales. Italian Journal of Agronomy (3)10:28.

Brunstrum, L.C. 1967. Crop yield and moisture studies with asphalt barriers. American Oil Company Report for Project 1681, M67-219. Whiting, IN: Amoco.

Brunstrum, L.C., L.E. Ott, and T.L. Spear. 1967 Increasing crop yields with underground asphalt moisture barriers. 7th World Petroleum Congress, April 2-9, 1967, Mexico City, Mexico.

Cameron, L., A.J.M. Smucker, and K. Walsh. 2013 Revolutionary technology aids thirsty crops during drought. Michigan State University Today, Jan. 16, 2013. http://msutoday.msu.edu/news/2013/ revolutionary-technology-aids-thirsty-cropsduring-drought/.

Chen, C., and T. Qian. 1984. Transformation and utilization of sand land and its beneficial result. A case study in Shapotou, Zhongwei, Ningxia. Journal of Desert Research 4:38-44 (in Chinese with English abstract).

Clay,J. 2004.World Agriculture and the Environment: A Commodity-by-Commodity Guide to Impacts and Practices. Chicago: Island Press.

Daka, A.E. 2001. Clay Pot Sub-Surface Irrigation as Water-Saving Technology for Small-Farmer Irrigation in Development of a Technological Package for Sustainable Use of Dambos by SmallScale Farmers. PhD dissertation, University of Pretoria. http://upetd.up.ac.za/thesis/available/ etd-09062001-093813/.

Demirel, K. 2012. Effects of Water Retention Barriers (WRB) that Placed under Soil on Soil Water Content and Turfgrass Plant Development. PhD disseration. Canakkale Onsekiz Mart University.

Demirel, K., and Y. Kavdir. 2013. Effect of soil water retention barriers on turfgrass growth and soil water content. Journal of Irrigation Science 31:689-700.
Erickson, A.E. 1972. Improving the water properties of sand soil. In Optimizing the Soil Physical Environment Toward Greater Crop Yields, D. Hillel, ed., 35-41. New York and London: Academic Press.

Erickson, A.E., C.M. Hansen, and A.J.M. Smucker. 1968a. The influence of sub-surface asphalt barriers on the water properties and the productivity of sand soils. In 9th International Congress of Soil Science Transactions 1(35):331-337.

Erickson, A.E., C.M. Hansen, A.J.M. Smucker, K.Y. Li, L.C. Hsi, T.S. Wang, and R.L. Cook. 1968b. Subsurface asphalt barriers for the improvement of sugarcane production and the conservation of water on sand soil. International Society of Sugarcane Technologists Proceedings, 13th Congress, Taiwan, 787-792.

Erickson, A.E., J.M. Tiedje, B.G. Ellis, and C.M. Hansen. 1971. A barriered landscape water renovation system for removing phosphate and nitrogen from liquid feedlot waste. In Proceedings of International Livestock Waste Conference, Columbus, Ohio. American Society of Agricultural Engineers.

Gao, W., D. Wang, and Z. Yang. 1996. Development of cement pitcher for pitcher irrigation and its application. Mountain Research 14:251-254 (in Chinese with English abstract).

Garrity, D.P., C. Vejpas, and W.T. Herrera.1992. Soil and Water Engineering for Paddy Field Management. International Rice Research Institute Annual Report, 413-421.

Graham, C., and H.S. Lin. 2012. Subsurface flow networks at the hillslope scale: Detection and Modeling. In Hydropedology: Synergistic Integration of Soil Science and Hydrology, $\mathrm{H}$. Lin, ed., 559-594. Waltham, MA: Elsevier.

Hakkarainen, M., and A. Albertsson. 2004. Environmental degradation of polyethylene. Advances in Polymer Science 169:177-199.

Hansen, C.M., and A.E. Erickson. 1969. Use of asphalt to increase water holding-capacity

of droughty sand soils. Industry and Engineering Chemical Product Research and Development 8:256-259.

Hillel, D. 2004. Introduction to Environmental Soil Physics. New York: Wiley Press.

Ismail, S.M., and K. Ozawa. 2007. Improvement of crop yield, soil moisture distribution and

water use efficiency in sandy soils by clay application, Applied Clay Science 37:81-89.

Kavdir,Y., K. Demirel, and A.J.M. Smucker. 2012. A new water retention technology; retaining soil water and nutrients in the plant root zone. In 8th International Soil Science Congress on Land Degradation and Challenges in Sustainable Soil 
Management,Vol. IV: 222-224, May 15-17, 2012, Izmir, Turkey.

Kimbrell, A. 2002. Fatal Harvest: The Tragedy of Industrial Agriculture. Washington, DC: Island Press.

Liu, J.-R., J.-X. Sun, X.-R. Xie, J.-X. Du, and Q. Wang. 2008. Effect of understratum-film on saline partition and establishment of high quality turf in heavy saline-alkali field of arid Hungriness oasis region. Acta Agrestia Sinica 16:202-207 (in Chinese with English abstract).

Liu, J., X. Xie, J. Sun, and J. Du. 2005. The techniques for planting lawn with film-bottomed tillage and water saving irrigation in sandy land of arid desert region. Scientia Silvae Sinica 41:89-93 (in Chinese with English abstract).

Mckenna, T. 2012. Feed the future deputy coordinator for development, Report before the senate foreign relations international development subcommittee. November 28, 2012. http://www.usaid.gov/news-information/ congressional-testimony/testimony-tjada-mckenna-feed-future-deputy-coordinator.

Mortland, M.M., A.E. Erickson, and J.F. Davis. 1957. Clay ammendments on sandy and organic soils. Quarterly Bulletin of the Michigan Agricultural Experiment Station 40(1):23-30. East Lansing, MI: Michigan State University.

OECD (Organization for Economic Cooperation and Development). 2008. Environmental Performance of Agriculture in OECD countries since 1990. Paris, France: Organization for Economic Cooperation and Development. www.oecd.org/tad/env/indicators.

Park, E.J.,W.J. Sul, and A.J.M. Smucker. 2007. Glucose additions to aggregates subjected to drying and wetting cycles promote carbon sequestration and aggregate stability. Soil Biology and Biochemistry Journal 39:2758-2768.

Rao, K.V.P., S.B. Varade, and H.K. Pande. 1972. Influence of subsurface barrier on growth, yield, nutrient uptake and water requirement of Rice (Oryza sativa). Agronomy Journal 64:578-580.

Ren, J., H. Wang, X.-L. Zhou, and D.-Q. Chen. 2000. Study on dynamic variation law of filmbottomed sandy soil moisture. Journal of Gansu Agricultural University 35:152-156 (in Chinese with English abstract).

Robertson, G.P., and P.M. Vitousek. 2009. Nitrogen in agriculture: Balancing the cost of an essential resource. Annual Review of Environmental Research 34:97-125, doi: 10.1146/annurev. environ.032108.105046.

Robertson, W.K., L.C. Hammond, G.K. Saxena, and H.W Lundy. 1973. Influence of water management through irrigation and a subsurface asphalt layer on seasonal growth and nutrient uptake of corn. Agronomy Journal 65:866-870.

Saunders, G. 1941. The claying of Finland. Journal of the Ministry of Agriculture 40:31-39.

Saxena, G.K., L.C. Hammond, and H.W. Lundy. 1971. Effect of an asphalt barrier on soil water and on yields and water use by tomato and cabbage. Journal of American Society for Horticultural Science 96:218-222.

Saxena, G.K. L.C. Hammond, and W.K. Robertson. 1973. Effects of subsurface asphalt layers on corn and tomato root systems. Agronomy Journal 65:191-194.

Scarborough, E.N., and W.C. Liebhardt. 1973. Subsurface asphalt moisture barrier in sandy soils. Vol. 401. Delaware Agricultural Experiment Station Bulletin Newark, DE: University of University.

Šimůnek, J., M. Šejna, H. Saito, M. Sakai, and M.Th. van Genuchten. 2008. The HYDRUS-1D software package for simulating the movement of water, heat, and multiple solutes in variably saturated media. Version 4.0. HYDRUS Software Ser. 3. Riverside, CA: University of California Riverside, Department of Environmental Science. Smucker, A.J.M. 1969. Asphalt Moisture Barriers Increase Water Use Efficiency in Rice and Sugarcane Cultures in Taiwan. Master's thesis, Michigan State University.

Smucker, A.J.M., and B. Basso. 2014. Global potential for a new subsurface water retention technology- converting marginal soil into sustainable plant production. In The Soil Underfoot: Infinite Possibilities for a Finite Resource, G.J. Churchman, ed., 315-324. Boca Raton, FL: CRC Press.

Smucker, A.J.M., G. Schultink, and K. Thelen. 2009a. SWRT enhancement of water use efficiency and economics of irrigated low water holding capacity sandy soils. Abstract for American Society of Soil Science. Pittsburgh, Pennsylvania, November, 2009.

Smucker, A.J.M., K. Thelen, S.G. Li, G. Schultink, and C. McKeown. 2009b. Site suitability assessment for developing sustainable cellulosic biomass feedstocks on marginal sandy soils in Michigan. Michigan Agricultural Bio-Energy Conference, Kalamazoo, Michigan, March, 2009.

Smucker, A.J.M., K.D. Thelen, and M. Ngouajio. 2012. A new soil water retention technology that doubled corn production during the 2012 drought. Annual Meeting of the International Soil Science Society of America, Tampa, Florida. https://scisoc.confex.com/crops/2013am/webprogram/Paper80350.html.
Smucker,A.J.M., Z.Yang, H. Li, and A.N. Kravchenko. 2010. Anthropogenic modifications of soil profiles can improve sustainable production on historically classified marginal soils. Abstract for American Society of Soil Science. Long Beach, California, November, 2010.

Steward, D.R., P.J. Bruss, X.Y.Yang, S.A. Staggenborg, S.M. Welch, and M.D. Apley. 2013. Tapping unsustainable groundwater stores for agricultural production in the High Plains Aquifer of Kansas, projections to 2110. Proceedings of the National Academy of Sciences September 110 (37):E3477-E3486.

Sumner, M.E., and E.C. Gilfillan. 1971. Asphalt barriers to improve productivity of sandy soils a preliminary assessment. Proceedings of South African Sugar Technology Association 165-168.

Sun, H., K. Li, A. Zhao, and X. Zhang. 2000. Infiltration characteristics of clay pots in sandy soil. Water Saving Irrigation 2:26-29 (in Chinese).

Wang, H., X. Sheng, and D.-H. Xu. 2000a. Effect of the film-bottomed sandy land on the soil temperature. Journal of Gansu Agricultural University 35:157-161 (in Chinese with English abstract).

Yang, Z., A.J.M. Smucker, G. Jiang, and X. Ma. 2012. Influence of the membranes on water retention in saturated homogeneous sand columns. International Symposium on Water Resource and Environmental Protection (ISWREP), 1590-1593. 